\title{
Community, Connections and Innovation in Emergency Remote Teaching and Learning
}

\author{
Sandra Healy \\ Kyoto Institute of Technology \\ (i)/0000-0003-4387-259X \\ DOI: https://dx.doi.org/10.46679/978819484836306 \\ 'I am what I am because of who we all are.' \\ Desmond Tutu, (1999), No Future Without Forgiveness.
}

\begin{abstract}
The emergence of the Covid-19 virus had an enormous impact on all of our lives and significantly affected the lives of first-year university students in Japan who began their tertiary education during the initial lockdown. This chapter examines the impact the move online had on these students by analysing videos created by them as part of their academic English as a Foreign Language (EFL) coursework. The videos were analysed and 12 themes emerged which were used as a foundation for new practices focusing on the development of community and connections in online courses, particularly the use of e-mentors.
\end{abstract}

Keywords: Online learning, emergency remote teaching and learning, digital inclusion, e-mentors, video analysis

\section{Introduction}

The emergence of the Covid-19 virus had an enormous impact on all of our lives in a multitude of ways. One group that was significantly affected was first-year university students in Japan as the initial pandemic-related lockdowns and the start of the academic year co-occurred in April 2020. While undergoing their transition into 
university life many students found themselves suddenly taking classes online rather than in the classroom face to face.

Worldwide, online courses have been gaining popularity due to the expansion of the internet and mobile learning (Duffin, 2020). However, universities in Japan have been slow to adopt online learning due to the lack of use of learning management systems in courses, and designated budgets and staff for the development of instructional technology (Nakamura, 2017). Mehran et al. (2017) found that even if technology is available its use was not guaranteed and stated that technology has not yet been normalized in Japanese educational settings (Bax, 2011).

Much research shows that online learning is a robust form of education (e.g., Nyugen, 2015; Stack, 2015). Research critiquing online education is plentiful, however, some researchers have found that online classes are more difficult to achieve success in, for example, $\mathrm{Xu}$ and Jaggars (2014) and Hart et al. (2018) found poorer outcomes for students in terms of course completion and grades.

According to figures from the Ministry of Education, Culture, Sports, Science and Technology (MEXT) in July 2020, all but one of Japan's national universities were either using a mixture of both online classes and face-to-face classes $(n=55)$ or were fully online $(n=30)$. The majority of private universities also used a mixture of online and face-to-face classes $(n=492)$ or were fully online $(n=187)$, with 145 universities remaining face-to-face (MEXT, 2020). The university where this study was conducted was fully online and the sudden switch to online learning as a result of the Covid-19 emergency meant that instead of well-thought-out and planned online courses we were engaged in Emergency Remote Teaching and Learning (ERTL). ERTL is a response to a crisis and attempts to recreate courses that would ordinarily have been delivered face-to-face, in a fully remote form, with the intention that they will return to 'normal' once the crisis is over (Hodges et al., 2020). This sudden shift to online learning was unprecedented and, at the university described here, the administration, teachers, and students alike were unprepared for it. This 


\section{This is a limited preview of the chapter.}

To read the full-text chapter, get access by purchasing this chapter or consider buying the complete book. If your library has subscription to EBSCOhost, the chapter including other chapters of the book can be accessed through your library.

This chapter is a part of the book, 'Development of Innovative Pedagogical Practices for a Modern Learning Experience' ISBN (paperback): 978-81948483-6-3; ISBN (ebook): 978-81-948483-7-0

Book DOI: https://dx.doi.org/10.46679/9788194848363

Available via CSMFL Bookstore, Amazon, Google Play Books, EBSCOhost \& EBSCO eBooks 
research is needed to explore how e-mentors can be used in different educational contexts in Japan.

\section{References}

Atkinson, D. (2010). Extended, embodied cognition and second language acquisition. Applied Linguistics, 31(5), 599-622. https://doi.org/10.1093/applin/amq009

Bettinger, E. P., \& Baker, R. B. (2014). The effects of student coaching: An evaluation of a randomized experiment in student advising. Educational Evaluation and Policy Analysis, 36(1), 3-19. https://doi.org/10.3102/0162373713500523

Bax, S. (2011). Normalisation revisited: The effective use of technology in language education. International Journal of Computer-Assisted Language Learning and Teaching, 1(2), 1-15. https://doi.org/10.4018/ijcallt.2011040101

Buchwald, D., Schantz-Laursen, B., \&Delmar, C. (2009). Video diary data collection in research with children: An alternative method. International Journal of Qualitative Methods, 8(1), 12-20. https://doi.org/10.1177/160940690900800102

Cooley, S. J., Holland, M. J., Cumming, J., Novakovic, E. G., \&Burns, V. E. (2014). Introducing the use of a semi-structured video diary room to investigate students' learning experiences during an outdoor adventure education groupwork skills course. Higher Education, 67(1), 105-121. https://doi.org/10.1007/s10734-013-9645-5

Dell, C. A., Dell, T. F., \& Blackwell, T. L. (2015). Applying universal design for learning in online courses: Pedagogical and practical considerations. Journal of Educators Online, 12(2), 166-192. https://doi.org/10.9743/JE0.2015.2.1

Dewaele, J. M. (2019). When elephants fly: The lift-off of emotion research in applied linguistics. The Modern Language Journal, 103(2), 533-536. https://doi.org/10.1111/modl.12576 
Dewaele, J. M., \& Li, C. (2020). Emotions in second language acquisition: A critical review and research agenda. Foreign Language World,196(1), 34-49.

Dewey, J. (1938). Experience and education. Kappa Delta Pi.

Dolan, E., and Johnson, D. (2009). Toward a holistic view of holistic undergraduate research experiences: An exploratory study of impact on graduate/postdoctoral mentors. Journal of Science Education Technology, 2009(18), 487-500. https://doi.org/10.1007/s10956-009-9165-3

Dörnyei, Z. (2005). The psychology of the language learner: Individual differences in second language acquisition. Mahwah.

Dörnyei, Z. (2014). Future self-guides and vision. The impact of self-concept on language learning, 7-18. https://doi.org/10.21832/9781783092383-003

Drake, J. K. (2011). The role of academic advising in student retention and persistence. About Campus, 16(3), 8-12. https://doi.org/10.1002/abc.20062

Duffin, E. (2020). E-learning and digital education - Statistics \& facts. https://www.statista.com/topics/3115/e-learning-and-digital-edu cation/

Eby, L. T., \& Dolan, E. L. (2015). Mentoring in postsecondary education and organizational settings. In P. J. Hartung, M. L. Savickas \& W. B. Walsh (Eds.), APA handbooks in psychology. APA handbook of career intervention, Vol. 2. Applications, 383-395). American Psychological Association. https://doi.org/10.1037/14439-028

Glaser, B.G., \& Strauss, A.L. (1967).The discovery of grounded theory: Strategies for qualitative research. Aldine deGruyter. https://doi.org/10.1097/00006199-196807000-00014

Hadfield, J., \& Dörnyei, Z. (2014). Motivating learning. Routledge. https://doi.org/10.4324/9781315833286

Hamburg, I. (2020). Creating innovative structures in workplace and vocational digital learning to ensure social distancing. In ICDS 
2020: The Fourteenth International Conference on Digital Society,124-127.

Hart, C. M., Friedmann, E., \& Hill, M. (2018). Online course-taking and student outcomes in California community colleges. Education Finance and Policy,13(1), 42-71. https://doi.org/10.1162/edfp_a_00218

Healy, S. (2021). COVID-19 pandemic-influenced changes to Japanese university student digital identity. In P. Clements, R. Derrah \& P. Ferguson (Eds.), Communities of teachers and learners. JALT. https://doi.org/10.37546/JALTPCP2020-44

Hoare, E., Bott, D., \& Robinson, J. (2017). Learn it, live it, teach it, embed it: Implementing a whole school approach to foster positive mental health and wellbeing through positive education. International Journal of Wellbeing, 7(3), 56-71. https://doi.org/10.5502/ijw.v7i3.645

Hodges, C., Moore, S., Lockee, B., Trust, T., \& Bond, A. (2020). The difference between emergency remote teaching and online learning. Educause Review, 27, 1-12.

Honda, H., Yoshikawa, K., Yamashina, Y., Yamato, Y., Terada, S., \&Goto, M. (2020). Association among social-networking service usage via smartphone, internet addiction, and psychological stress in Japanese physical therapy university students: a single-university cross-sectional study. Journal of Physical Therapy Science, 32(9), 591-596. https://doi.org/10.1589/jpts.32.591

Ito, M., Baumer, S., Bittanti, M., Boyd, D., Cody, R., Herr-Stephenson, B., Horst, H.A., ... \& Tripp, L. (2010). Hanging out, messing around, and geeking out. MIT Press. https://doi.org/10.7551/mitpress/8402.001.0001

Kwan, C., Gitimoghaddam, M., \& Collet, J. P. (2020). Effects of social isolation and loneliness in children with neurodevelopmental disabilities: A scoping review. Brain Sciences, 10(11), 786. https://doi.org/10.3390/brainsci10110786 
Lave, J., \& Wenger, E. (1991). Situated learning: Legitimate peripheral participation. Cambridge University Press.https://doi.org/10.1017/CB09780511815355

Lo, Y. F. (2010). Implementing reflective portfolios for promoting autonomous learning among EFL college students in Taiwan. Language Teaching Research, 14(1), 77-95. https://doi.org/10.1177/1362168809346509

McCosker, A., Suchowerska, R., \& Wilson, C. (2019) Digital mentors: The heart of the digital revolution. Swinburne university of Technology. https://apo.org.au/node/265591

Meesong, K., \& Jaroongkhongdach, W. (2016). Autonomous language learning: Thai undergraduate students' behaviors. Thai TESOL Journal, 29(2), 156-186.

Mehran, P., Alizadeh, M., Koguchi, I., \& Takemura, H. (2017). Are Japanese digital natives ready for learning English online? A preliminary case study at Osaka University. International Journal of Educational Technology in Higher Education,14(1), 1-17. https://doi.org/10.1186/s41239-017-0047-0

Meschitti, V., \& Lawton-Smith, H. (2017). Does mentoring make a difference for women academics? Evidence from the literature and a guide for future research. Journal of Research in Gender Studies, 7(1), 166-199. https://doi.org/10.22381/JRGS7120176

MEXT. (2020). A report on the status of classes implementation at Japanese universities due to the novella coronavirus. https://www.mext.go.jp/content/20200717-mxt_kouhou01-000004 520_2.pdf

Nakamura, M. (2017). The state of distance education in Japan. Quarterly Review of Distance Education, 18(3), 75-87.

National Institute for Educational Policy Research (NIER). Programme for International Student Assessment information. https://www.nier.go.jp/kokusai/pisa 
Nguyen, T. (2015). The effectiveness of online learning: Beyond no significant difference and future horizons. MERLOT Journal of Online Learning and Teaching,11(2): 309-310.

Okuda, Y. (2019). Daigakusei no keitai to pasokon no riyoujoukyou [Smartphone or PC: IT gadget usage among university students]. Bulletin of Faculty of Management Fukuyama Heisei University,15, 145-155.

Ono, Y., \& Shouji, K. (2015). Bukatsudouniokeru Senpai Kouhai Kankei no Kenkyu [Research about senior-junior relationships at club activities]. The Annual Report of Educational Psychology in Japan, 63, 438-452. https://doi.org/10.5926/jjep.63.438

Otani T. (2007). "SCAT" A qualitative analysis method by four-step coding: Easy startable and small scale data applicable process of theorization. Bulletin of the Graduate School of Education and Human Development (Educational Sciences), Nagoya University, 54(2), 27-44. Pavlenko, A. (2013). The affective turn in SLA: From 'affective factors' to 'language desire' and 'commodification of affect'. The Affective Dimension in Second Language Acquisition, 3-28.

Prior, M. T. (2019). Elephants in the room: An "affective turn," or just feeling our way? The Modern Language Journal, 103(2), 516-527. https://doi.org/10.1111/modl.12573

Qie, N., Rau, P.-L. P., Wang, L., \& Ma, L. (2019). Is the Senpai-Kouhai relationship common across China, Korea, and Japan? Social Behavior and Personality: An International Journal,47(1), 1-12. https://doi.org/10.2224/sbp.7404

Ragins, B., \& Kram, K. (2007). The handbook of mentoring at work. Sage. Rose, D. H., \& Meyer, A. (2002). Teaching every student in the digital age: Universal design for learning. Association for Supervision and Curriculum Development.

Ryan, S., \& Irie, K. (2014). Imagined and possible selves: Stories we tell ourselves about ourselves. In S. Mercer \&M. Williams(Eds.), 
Multiple perspectives on the self in SLA. Multilingual Matters. https://doi.org/10.21832/9781783091362-009

Sade, L. A. (2011). Emerging selves, language learning and motivation through the lens of chaos. Identity, Motivation and Autonomy in Language Learning, 54, 42-56. https://doi.org/10.21832/9781847693747-005

Stack, S. (2015). Learning outcomes in an online vs traditional course. International Journal for the Scholarship of Teaching and Learning, 9(1), Article 5. https://doi.org/10.20429/ijsotl.2015.090105.

Tominaga, A., \& Kogo, C. (2018). Attributes of good E-learning mentors according to learners. Universal Journal of Educational Research, 6(8), 1777-1783. https://doi.org/10.13189/ujer.2018.060822

Van Deursen, A. J., \& Van Dijk, J. A. (2019). The first-level digital divide shifts from inequalities in physical access to inequalities in material access. New Media \&Society, 21(2), 354-375. https://doi.org/10.1177/1461444818797082

Vuorela, M., \& Nummenmaa, L. (2004). Experienced emotions, emotion regulation and student activity in a web-based learning environment. European Journal of Psychology of Education, 19(4), 423-436. https://doi.org/10.1007/BF03173219

Wenger, E. (1998). Communities of practice: Learning as a social system. Systems Thinker, 9(5), 2-3.

Wenger, E. (2011). Communities of practice: A brief introduction. National Science Foundation.

Xu, D., \& Jaggars, S. S. (2014). Performance gaps between online and face-to-face courses: Differences across types of students and academic subject areas. The Journal of Higher Education, 85(5), 633-659. https://doi.org/10.1353/jhe.2014.0028 


\section{About the author}

Sandra Healy is an Associate Professor at Kyoto Institute of Technology in Japan in the Faculty of Arts and Sciences. Her current research interests include using technology in English language education to improve language learning outcomes, and provide opportunities for intercultural communication and address diversity and inclusion for all. 